Article

\title{
Enhanced Degradation of Phenolic Compounds in Coal Gasification Wastewater by Methods of Microelectrolysis Fe-C and Anaerobic-Anoxic-Oxic Moving Bed Biofilm Reactor (A2O-MBBR)
}

\author{
Do Tra Huong ${ }^{1, *}$, Van Tu Nguyen ${ }^{2, *}$, Xuan Linh $\mathrm{Ha}^{3}$, Hien Lan Nguyen Thi ${ }^{1}$, Thi Thoa Duong ${ }^{1}$, \\ Duy Chinh Nguyen ${ }^{4,5}$ and Hong-Tham Nguyen Thi ${ }^{4,5, *}$ \\ 1 Thai Nguyen University of Education, Thai Nguyen University, Thai Nguyen Province 250000, Vietnam; \\ lannth.chem@tnue.edu.vn (H.L.N.T.); duongthoasp@gmail.com (T.T.D.) \\ 2 Institute of Chemistry and Materials, Institute of Military Science and Technology, \\ Hanoi City 100 000, Vietnam \\ 3 International School, Thai Nguyen University, Thai Nguyen 250000, Vietnam; haxuanlinh.tnu@gmail.com \\ 4 NTT Hi-Tech Institute, Nguyen Tat Thanh University, Ho Chi Minh City 700000, Vietnam; \\ ndchinh@ntt.edu.vn \\ 5 Center of Excellence for Green Energy and Environmental Nanomaterials, Nguyen Tat Thanh University, \\ Ho Chi Minh City 700000, Vietnam \\ * Correspondence: huongdt.chem@tnue.edu.vn (D.T.H.); nguyenvantu882008@yahoo.com (V.T.N.); \\ nththam@ntt.edu.vn (H.-T.N.T.)
}

Received: 31 August 2020; Accepted: 17 September 2020; Published: 7 October 2020

\begin{abstract}
The coal gasification wastewater figures prominently among types of industrial effluents due to its complex and phenolic composition, posing great difficulty for conventional water treatment processes. Since the coking wastewater is toxic and mutagenic to humans and animals, treatment of coal gasification wastewater is genuinely necessary. In this study, we established a lab-scale A2O (Anaerobic-Anoxic-Oxic) with moving bed biological reactor (MBBR) system and evaluated some water indicators of wastewater pretreated with internal electrolysis, of wastewater output of the established A2O-MBBR system, and of the wastewater treated by the combination thereof. The wastewater was taken from a coking plant at Thai Nguyen Iron and Steel Joint Stock Company in Vietnam. $\mathrm{COD}, \mathrm{BOD}_{5}, \mathrm{NH}_{4}{ }^{+}-\mathrm{N}$, phenol, and $\mathrm{pH}$ of the input coal gasification wastewater were 2359, $1105,319,172 \mathrm{mg} / \mathrm{L}$, and $8 \pm 0.1$, respectively. The conditions of internal electrolysis were as follows: $720 \mathrm{~min}$ of reaction time, $\mathrm{pH}=4,25 \mathrm{~g} / \mathrm{L} \mathrm{Fe}-\mathrm{C}$ dosage, and $100 \mathrm{mg} / \mathrm{L}$ PAM dosage. After internal electrolysis process, the removal of $\mathrm{COD}, \mathrm{BOD}_{5}, \mathrm{NH}_{4}{ }^{+}-\mathrm{N}$, and phenol were $53.7 \%, 56.7 \% 60.5 \%$, and $73.3 \%$, respectively. After $24 \mathrm{~h}$ of treatment, the treatment efficiencies of the combined treatment process are as follows: $100 \%$ phenol removal, $71.3 \%$ of TSS removal; $97.7 \%$ reduction of $\mathrm{BOD}_{5}$, and $97.1 \%$ reduction of COD; total $\mathrm{N}$ content reduced by $97.6 \%$; total $\mathrm{P}$ content decreased by $81.6 \%$; and $\mathrm{NH}_{4}{ }^{+}-\mathrm{N}$ content decreased by $97.5 \%$. All above indicators after treatment have met QCVN 52: 2017/BTNMT (column A) Vietnamese standard for steel industry wastewater.
\end{abstract}

Keywords: internal electrolysis; Fe-C materials; coal gasification wastewater; A2O-MBBR

\section{Introduction}

The coal gasification wastewater is among the most difficult-to-treat wastewaters due to its complex and phenolic composition, which contains a large number of organic compounds and cyanide [1]. Since it is toxic and mutagenic to humans and animals, treatment of coal gasification wastewater is genuinely necessary. However, in Vietnam, coal gasification wastewater has been treated by traditional 
methods, often combining two main processes, pretreatment by physical and chemical methods and subsequent biological process. Of which, physicochemical pretreatment processes involved the removal of phenol and $\mathrm{NH}_{3}$ from highly concentrated pollutants to facilitate the subsequent biological treatment and might include extraction, extraction, and autoclaving, filler, flocculation, dilution, electrochemical, Fenton, and oxidation [2-5].

However, such pretreatment methods still present certain disadvantages such as high treatment cost, technological complexity, and generation of secondary pollution. In recent years, internal electrolysis has been gaining popularity in studies involving pretreatment of wastewater, especially industrial wastewater polluted with organic substances that are difficult to biodegrade and present in high concentration. The treatment method could be utilized in a wide range of industries ranging from textile and pharmaceutical to treatment of domestic and coking wastewater [5-9].

Internal electrolysis allows following reactions to occur $[5,7]$ :

1. The effect of electric fields: The electrical field generated microcells in wastewater could trigger the movement of pollutants to move to opposite electrode, where redox reaction would occur against charged pollutants. As a result, chemical structure of the pollutants would be transformed or degraded.

2. The reducing effect of hydrogen: In the acidic medium, the following reaction produces atoms $[\mathrm{H}]$.

$$
\mathrm{Fe}+2 \mathrm{H}^{+} \rightarrow \mathrm{Fe}^{2+}+2[\mathrm{H}]
$$

Then, atoms $[\mathrm{H}]$ will reduce pollutants. For example, $\mathrm{NO}_{2}^{-}$group pollutants will be reduced and converted to amino group $\left(\mathrm{NH}_{2}\right)$ compounds.

3. The effect of metallic iron: The metallic elements that have weaker reactivity than iron could exchange electrons on the metallic iron surface. Then metal ions with strong toxicity or organic substances will be reduced by iron to metal ions in a less toxic state. For example, $\mathrm{Cr}(\mathrm{VI})$ having $\mathrm{E}^{0}\left(\mathrm{Cr}_{2} \mathrm{O}_{7}^{2-} / \mathrm{Cr}^{3+}\right)=1.36 \mathrm{~V}$ and strong oxidizing properties would react with metal iron:

$$
2 \mathrm{Fe}+\mathrm{Cr}_{2} \mathrm{O}_{7}^{2-}+14 \mathrm{H}^{+} \rightarrow 2 \mathrm{Fe}^{3+}+2 \mathrm{Cr}^{3+}+7 \mathrm{H}_{2} \mathrm{O}
$$

Then, $\mathrm{Cr}(\mathrm{VI})$ with strong oxidizing properties will be converted to $\mathrm{Cr}(\mathrm{III})$ with weak reducing properties. In acidic conditions, iron also reduce organic substances containing $\mathrm{NO}_{2}^{-}$group to $\mathrm{NH}_{2}$ group.

$$
\mathrm{C}_{6} \mathrm{H}_{5} \mathrm{NO}_{2}+3 \mathrm{Fe}+6 \mathrm{H}^{+} \rightarrow \mathrm{C}_{6} \mathrm{H}_{5} \mathrm{NH}_{2}+3 \mathrm{Fe}^{2+}+2 \mathrm{H}_{2} \mathrm{O}
$$

4. Reducing effect of $\mathrm{Fe}^{2+}$ ions: Iron oxidized to iron $\mathrm{Fe}^{2+}, \mathrm{Fe}^{2+}$ has high reducing properties. For $\mathrm{Cr}$ (VI), the reduction reaction occurs as follows.

$$
6 \mathrm{Fe}^{2+}+14 \mathrm{H}^{+} \rightarrow 6 \mathrm{Fe}^{3+}+2 \mathrm{Cr}^{3+}+7 \mathrm{H}_{2} \mathrm{O}
$$

5. The flocculation effect of iron ions: In acidic wastewater, metallic iron will corrode, thus expediting the production of $\mathrm{Fe}^{2+}$ and $\mathrm{Fe}^{3+}$ ions. In the presence of $\mathrm{O}_{2}$, following reactions will occur in alkaline environments.

$$
\begin{gathered}
\mathrm{Fe}^{2+}+2 \mathrm{OH}^{-} \rightarrow \mathrm{Fe}(\mathrm{OH})_{2} \\
4 \mathrm{Fe}^{2+}+8 \mathrm{OH}^{-}+\mathrm{O}_{2}+2 \mathrm{H}_{2} \mathrm{O} \rightarrow 4 \mathrm{Fe}(\mathrm{OH})_{3}
\end{gathered}
$$

The generated $\mathrm{Fe}(\mathrm{OH})_{2}$ and $\mathrm{Fe}(\mathrm{OH})_{3}$ could adsorb organic substances, thus contributing to the treatment process. 
6. The effect of chemical precipitation: $\mathrm{Fe}^{2+}$ and $\mathrm{Fe}^{3+}$ ions, when being in contact with anions, precipitate into compounds such as $\mathrm{FeS}, \mathrm{Fe}_{3}\left[\mathrm{Fe}(\mathrm{CN})_{6}\right]_{2}$, and $\mathrm{Fe}_{4}\left[\mathrm{Fe}(\mathrm{CN})_{6}\right]_{3}$. All of which could settle quickly and are easily removed from the wastewater.

Past studies involving treatment of gasified coal wastewater often focused on anaerobic-aerobic (AO), A2O, UASB, SBR, and FBR method [10-15]. However, recent advances have shown that combinations thereof, such as A2O (Anaerobic-Anoxic-Oxic) with moving bed biological reactor (MBBR) may offer certain advantages including the oxidation and decomposition of pollutants in anaerobic reaction, thus leading to reduced wastewater concentration and toxicity and allowing the possibility for pollutants to biodegrade. This, in turn, improves the $\mathrm{N}$ removal, $\mathrm{NH}_{4}^{+}$nitrification, and antinitrification in subsequent biological processes in the reactor with mobile media biofilm [14]. This approach was further extended by integrating internal electrolysis as the pretreatment process preceding the A2O-MBBR system to treat wastewater that contains pollutants with high $\mathrm{COD}, \mathrm{NH}_{4}^{+}$, and $\mathrm{N}$ content and effluents that are difficult to biodegrade such as discharges from coal gasification and coking processes [16-19]. In this study, we aimed to improve treatment process for real coking wastewater by comparing water indicators of effluents treated by various processes including internal electrolysis with Fe-C materials, the A2O-MBBR integrated system, and a combinational process in which internal electrolysis treatment preceded the A2O-MBBR.

\section{Materials and Methods}

\subsection{Fabrication of Materials}

Fe powder with particle size of smaller than $50 \mu \mathrm{m}$ and purity of $99.9 \%$, graphite powder with particle size of $50 \mu \mathrm{m}$ and $99.95 \%$ purity, and $\left(\mathrm{NH}_{4}\right)_{2} \mathrm{CO}_{3}$ were purchased from Shanghai Chemical Co. Ltd. (Shanghai, China).

The Fe-C internal electrolytic material sample was prepared as follows. A mixture containing $95 \%$ $\mathrm{Fe}, 3 \%$ graphite, and $2 \%$ bentonite binder additive (weight ratio) was first prepared. The mixture was then pressed into blocks, dried at $80-105^{\circ} \mathrm{C}$ for $2 \mathrm{~h}$, sintered at $500-600{ }^{\circ} \mathrm{C}$ for $4 \mathrm{~h}$, and then allowed to cool naturally. The material was then stored in a desiccator for use in further studies.

\subsection{Establishment of the A2O-MBBR System}

\subsubsection{Culturing Aerobic Activated Sludge}

Activated sludge was taken from the coking plant of Thai Nguyen Iron and Steel Joint Stock Company and was added with isolated bacteria strains with nitrification activities. The sludge was then added with $1 \mathrm{~L}$ of electrolytically treated wastewater and supplemented with nutrition resources with the ratio C:N:P $=100: 5: 1$ and $1.0 \mathrm{~g}$ of microbiological preparations that are used to treat high ammonium wastewater. Dissolved oxygen content in the aeration tank was 1.5-3.0 mg/L. Air was blown into the tank for $12 \mathrm{~h}$ and the tank was allowed to settle for $2 \mathrm{~h}$. Afterwards, clear water was removed, and wastewater and new sources of nutrients were added. This process was repeated several times over a period of 1 week. In the following week, the aeration time was reduced to $6 \mathrm{~h}$. The activated sludge domestication was conducted at room temperature with $\mathrm{pH}$ value of $6.5-7.0$ and lasted for 2 weeks.

\subsubsection{Culturing Anoxic Activated Sludge}

Activated sludge was collected from a coking plant at Thai Nguyen Iron and Steel Joint Stock Company. The sludge was added with $1 \mathrm{~L}$ of wastewater treated with internal electrolysis and with nutritional supplement to ensure the ratio C:N:P = 150:5:1, followed by addition of $1.0 \mathrm{~g}$ of microbiological preparations that are used to treat wastewater with high ammonium content. Dissolved oxygen content in the anoxic tank was from 1.0 to $2.0 \mathrm{mg} / \mathrm{L}$. Culture time was $24 \mathrm{~h}$ and the subsequent settle period was $2 \mathrm{~h}$. Clear water was then removed and after that, new wastewater and 
sources of nutrients were poured into the tank. The activated sludge domestication was conducted at room temperature with $\mathrm{pH}$ value of 6.5-7.0 and lasted from 15 to 20 days.

\subsubsection{Culturing Oxic Activated Sludge}

Activated sludge in the oxic tank was prepared identically to sludge in the anoxic tank except that the sludge domestication lasted 1 month instead of 15-20 days. We isolated bacteria from the tanks to determine bacterial concentration and the growth of microorganisms in the reaction tanks (Figure 1).

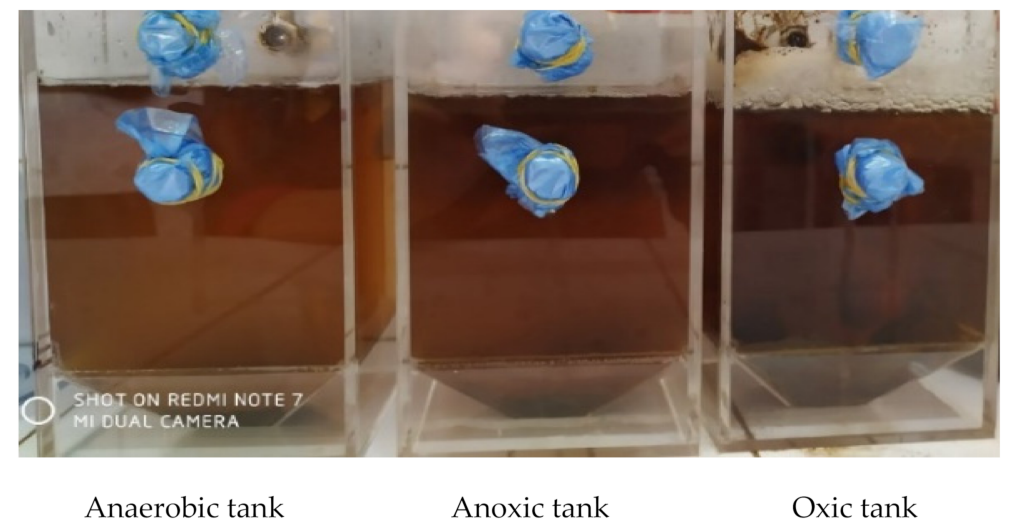

Figure 1. Activated sludge culture in the laboratory.

Figure 2 depicts the design of the A2O-MBBR system. Each tank has the volume of $3 \mathrm{~L}$ and has many different water inlets and outlets to facilitate the experiment and selection of retention time.

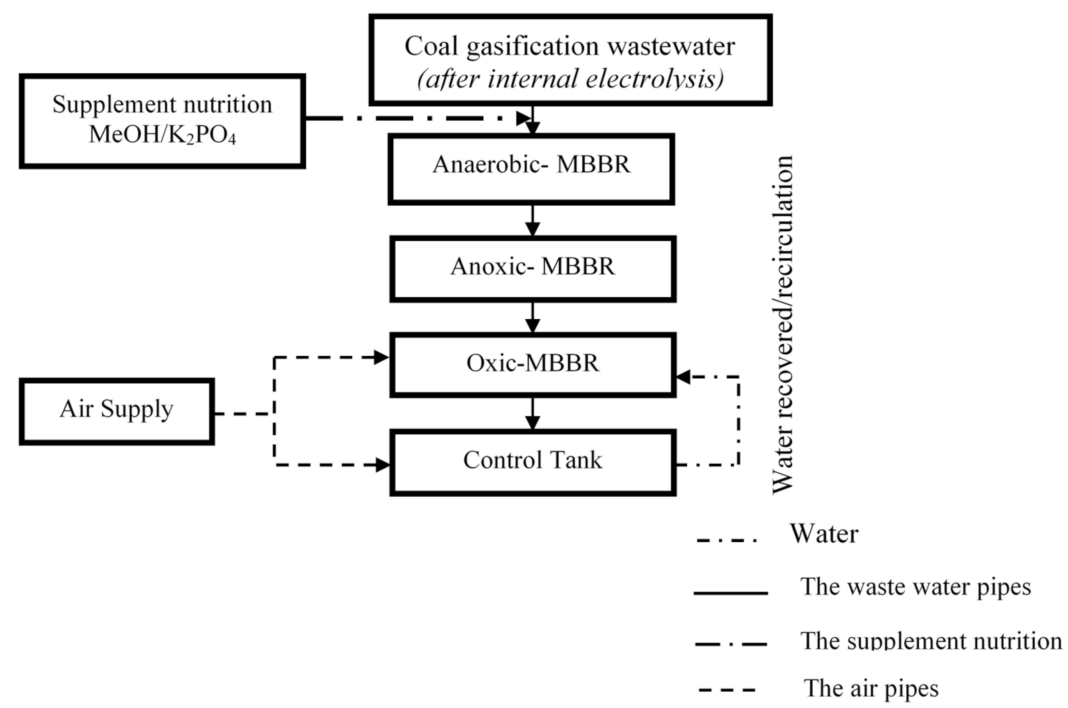

Figure 2. Diagram of A2O-MBBR system.

\subsubsection{Activated Sludge Culture}

Aeration in the aeration tank was performed so that dissolved $\mathrm{O}_{2}$ (DO) content ranged from 5 to $8 \mathrm{mg} / \mathrm{L}$. DO in the anoxic tank was maintained in the range of 1-2 mg/L by stirring for $150 \mathrm{~min}$. The length of the stirring paddle was $3 \mathrm{~cm}$. In all tanks, MBBR type biochip was supplemented. Per liter of wastewater, $1 \mathrm{~g}$ of growing media was added to the tanks. Table 1 summarizes initial parameters of the system. 
Table 1. Initial operating parameters of A2O-MBBR system.

\begin{tabular}{cccccc}
\hline Reaction Tank & COD (mg/L) & MLSS (mg/L) & pH & DO (mg/L) & Retention Time (h) \\
\hline Anaerobic & & $1800-2000$ & & - & 14 \\
Anoxic tank & 2359 & $2000-2300$ & $7.5-8$ & $1-2$ & 6 \\
Aerobic & & $4000-4500$ & & $5-8$ & 4 \\
\hline
\end{tabular}

MLSS is the activated sludge concentration.

After initial parameters had been studied, wastewater pretreated with internal electrolysis (adjusted $\mathrm{pH}=7$ ) was then treated using the A2O-MBBR system with following retention time: $24 \mathrm{~h}$ in anaerobic, $6 \mathrm{~h}$ in anoxic, and $4 \mathrm{~h}$ in aerobic tank. The initial and post-treatment phenolic concentrations of coke wastewater were determined on the HPLC Waters ACQUITY Arc instrument at the University of Education-Thai Nguyen University equipped with chromatographic column C18 Inertsil ODS $(5 \mu \mathrm{m}, 250 \times 3 \mathrm{~mm})$, GL Sciences Inc, Tokyo, Japan. Optimal conditions for the determination of phenol content are as follows: wavelength of $272 \mathrm{~nm}$, ratio of phosphate buffer solution mixture $(\mathrm{pH}=4)$ to acetonitrile solution $(\mathrm{pH}=3)$ of $30: 70(v / v)$, flow rate of $1.0 \mathrm{~mL} / \mathrm{min}$, and column temperature of $30^{\circ} \mathrm{C}$. TSS, BOD5, COD, total $\mathrm{N}$, total $\mathrm{P}$, and $\mathrm{NH}_{4}^{+}-\mathrm{N}$ indicators were determined at Thai Nguyen Center for Natural Resources and Environment Monitoring.

\section{Results and Discussion}

\subsection{Characterization of As-Synthesized Fe-C Material}

\subsubsection{SEM-EDS Analysis of Fe-C}

SEM-EDS image analysis results are shown in Figures 3 and 4, and Table 2. SEM image analysis results show that the structure of $\mathrm{Fe}$ and $\mathrm{C}$ powder particles is distributed relatively evenly on the surface, and they are smaller as $50 \mu \mathrm{m}$. EDS analysis results (Table 2) show that the main elements are $\mathrm{Fe}, \mathrm{C}$, and $\mathrm{O}$, and in addition, some other impurity elements such as $\mathrm{Si}, \mathrm{Al}$, and $\mathrm{Ca}$ are present. The occurrence of $\mathrm{O}$ in the analytical results shows that during the preservation of the sample, it is much oxidized on the surface. Other impurity elements $(\mathrm{Si}, \mathrm{Al}$, and $\mathrm{Ca}$ ) appear due to the bentonite binder.

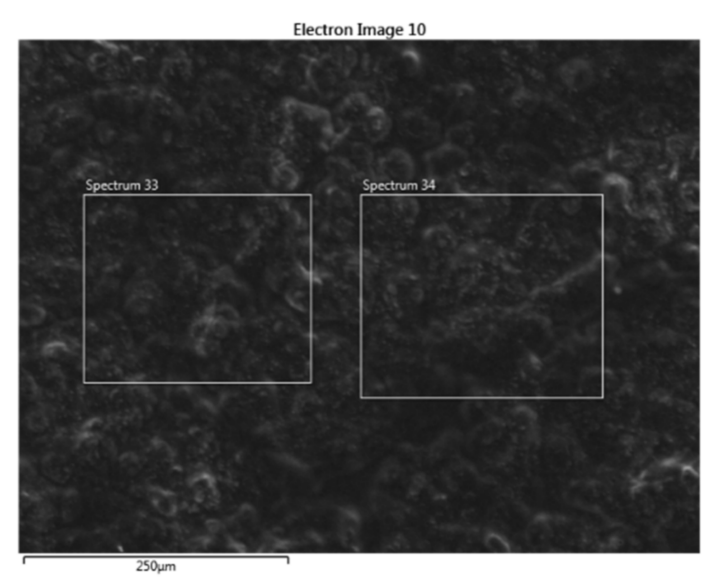

Figure 3. SEM image of Fe-C material. 


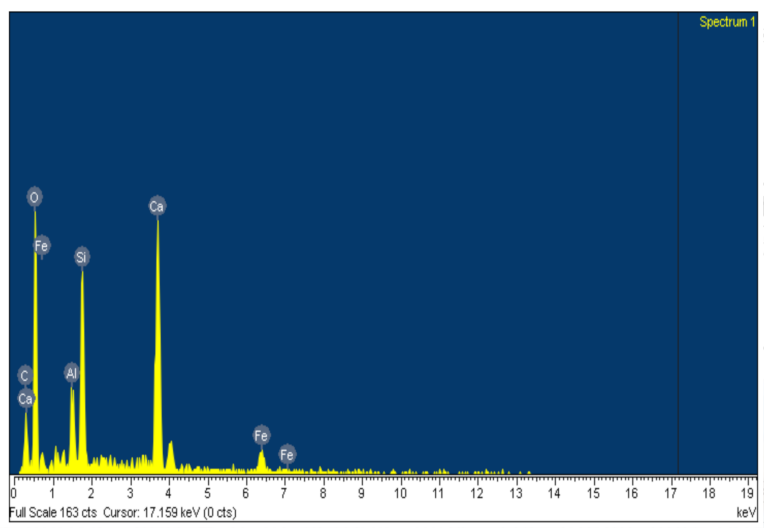

Figure 4. EDS pattern of Fe-C material.

Table 2. Elemental analysis of Fe-C material.

\begin{tabular}{ccc}
\hline Element & Weigh (\%) & Atomics (\%) \\
\hline $\mathrm{C}$ & 14.59 & 23.57 \\
$\mathrm{O}$ & 50.16 & 60.86 \\
$\mathrm{Al}$ & 1.89 & 1.36 \\
$\mathrm{Si}$ & 5.47 & 3.78 \\
$\mathrm{Ca}$ & 5.40 & 2.61 \\
$\mathrm{Fe}$ & 22.48 & 7.81 \\
Total & 100.00 & 100.00 \\
\hline
\end{tabular}

\subsubsection{XRD Analysis of Fe-C}

The results of XRD analysis (Figure 5) showed that Fe in the Fe-C sample was oxidized, there appeared structures of $\mathrm{Fe}_{3} \mathrm{O}_{4}$ and $\mathrm{Fe}_{2} \mathrm{O}_{3}$ on the surface of the material. It is possible to see the peaks of these oxides corresponding to the peaks at $45.5^{\circ}$, of $\mathrm{Fe}_{3} \mathrm{O}_{4}$ at $63^{\circ}$, of $\mathrm{Fe}_{2} \mathrm{O}_{3}$ at $36^{\circ}$, and of $\mathrm{Fe}$ appears at lower intensity at $34.5^{\circ}$.

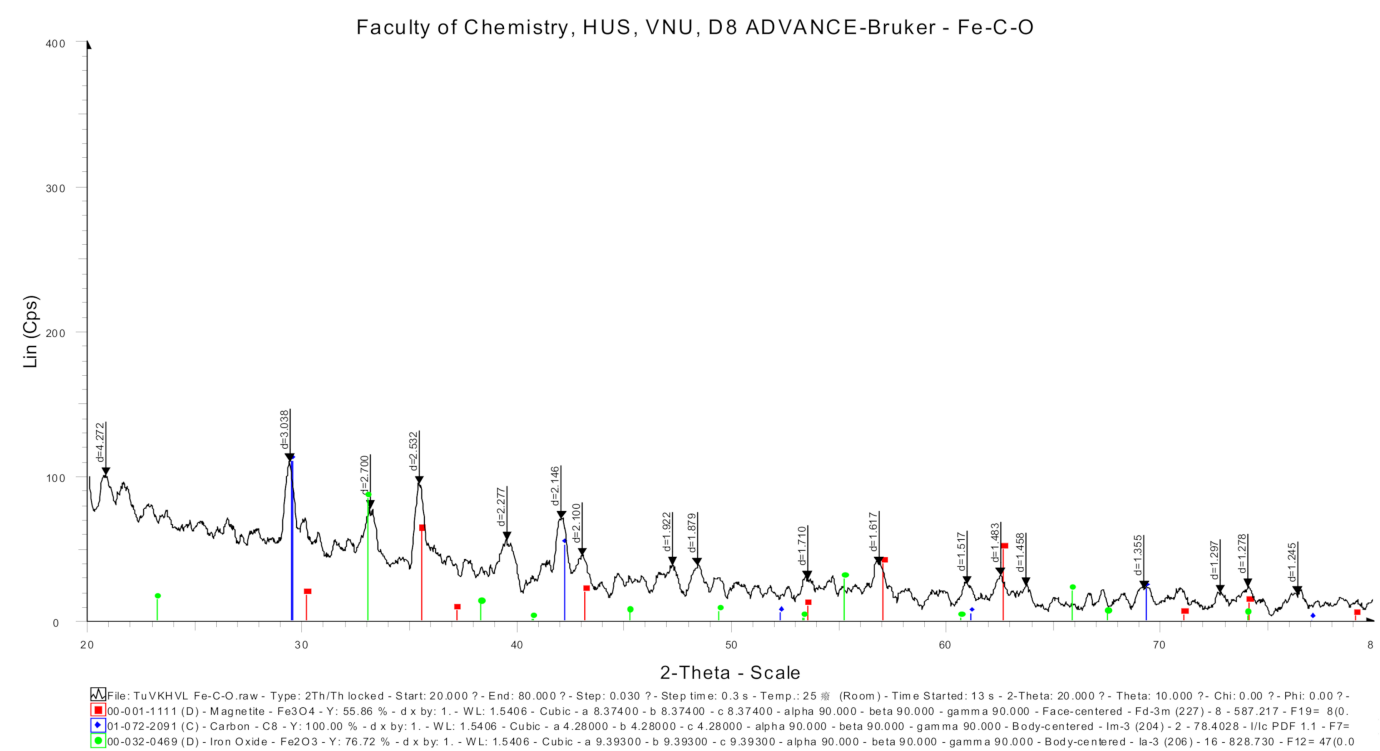

Figure 5. XRD pattern of Fe-C material. 


\subsection{Wastewater Treatment Using Fe-C Internal Electrolysis Material}

Figures 6 and 7 show the HPLC phenol analysis results of the coking wastewater before and after internal electrolysis treatment, respectively. Internal electrolysis was carried out with following conditions: initial phenol concentration of $172.0 \mathrm{mg} / \mathrm{L}, 25 \mathrm{~g} / \mathrm{L}$ of Fe-C internal electrolyte material, $720 \mathrm{~min}$ of shaking time, $\mathrm{pH}=4$, and shaking speed of $200 \mathrm{rpm}$. The HPLC analysis showed that the initial phenol content had degraded by $73.3 \%$ after internal electrolysis treatment (Table 3).

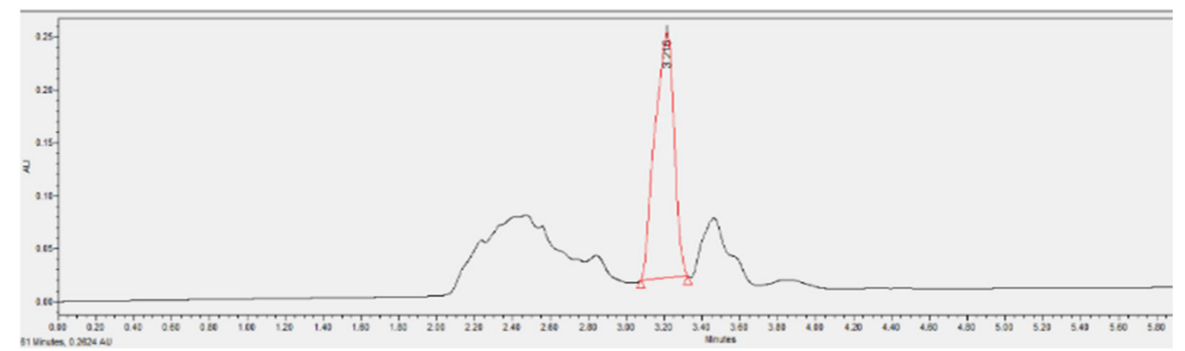

Figure 6. Chromatogram of the phenol containing wastewater before treatment with Fe-C internal electrolyte material.

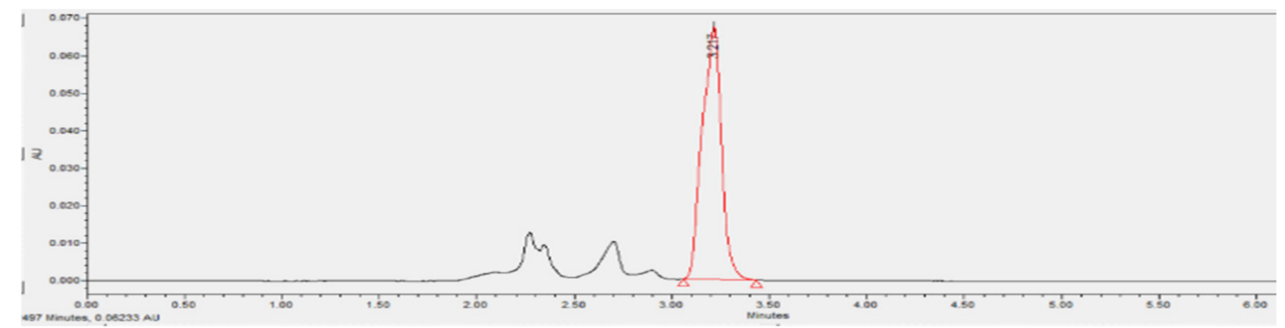

Figure 7. Chromatogram of the phenol containing wastewater after treatment with $\mathrm{Fe}-\mathrm{C}$ internal electrolyte material.

Table 3. Characteristics of coking wastewater before and after internal electrolysis treatment with Fe-C material.

\begin{tabular}{|c|c|c|c|c|c|}
\hline \multirow{2}{*}{ Parameters } & \multirow{2}{*}{ Unit } & \multirow{2}{*}{ Method of Analysis } & \multicolumn{2}{|c|}{ Result (mg/L) } & \multirow{2}{*}{$\begin{array}{c}\text { Efficiency } \\
\text { H (\%) }\end{array}$} \\
\hline & & & Before & After & \\
\hline $\mathrm{pH}$ & - & TCVN 6492:2011 & 8.3 & 6.7 & - \\
\hline DO & $\mathrm{mg} / \mathrm{L}$ & TCVN 7325:2004 & 0.6 & 2.8 & - \\
\hline TSS & $\mathrm{mg} / \mathrm{L}$ & SMEWW 2540 D:2012 & 156.2 & 76.5 & 51.02 \\
\hline $\begin{array}{l}\mathrm{BOD}_{5} \\
\left(20^{\circ} \mathrm{C}\right)\end{array}$ & $\mathrm{mg} / \mathrm{L}$ & TCVN 6001-1:2008 & 1150.0 & 498.0 & 56.7 \\
\hline $\mathrm{COD}$ & $\mathrm{mgO}_{2} / \mathrm{L}$ & SMEWW 5220C:2012 & 2231.0 & 1032.0 & 53.7 \\
\hline Phenol & $\mathrm{mg} / \mathrm{L}$ & TCVN 6216:1996 & 172.0 & 45.9 & 73,32 \\
\hline $\mathrm{CN}^{-}$ & $\mathrm{mg} / \mathrm{L}$ & $\begin{array}{l}\text { SMEWW4500 } \\
\text { CN }^{-} B: 2012\end{array}$ & 0.05 & $<0.01$ & - \\
\hline Total N & $\mathrm{mg} / \mathrm{L}$ & TCVN 6638:2000 & 865.0 & 562.4 & 34.98 \\
\hline $\mathrm{NH}_{4}^{+}-\mathrm{N}$ & $\mathrm{mg} / \mathrm{L}$ & TCVN 6179-1:1996 & 391.0 & 156.0 & 60.1 \\
\hline Total P & $\mathrm{mg} / \mathrm{L}$ & TCVN 6202:2008 & 16.1 & 8.5 & 47.2 \\
\hline
\end{tabular}

The results showed that Fe-C internal electrolysis materials had decomposed $73.32 \%$ of phenol, $51.02 \%$ of TSS, $56.70 \%$ of $\mathrm{BOD}_{5}, 53.74 \%$ of COD, $34.98 \%$ of total nitrogen, $47.20 \%$ of total phosphorus, and $60.10 \%$ of $\mathrm{NH}_{4}{ }^{+}-\mathrm{N}$.

The mechanism of phenol degradation in the internal electrolysis process with $\mathrm{Fe}-\mathrm{C}$ material has been presented previously [6]. Accordingly, the decomposed phenol is converted to a less toxic intermediate compound. The mechanism suggests that the transformation of toxic organic compounds into biodegradable intermediates is caused by the microelectrolysis, which produces 
radicals and oxidants to destroy benzene rings and chemical bonds situating at side chains [20]. On the other hand, based on the formation of an electric field that induces microelectron currents in the galvanic cell reaction, electron transfer effectively stimulates the growth of microorganisms and active metabolic enzymes and moreover, promotes the biodegradation of microorganisms [21]. Furthermore, iron-carbon microelectrolysis is also capable of efficiently degrading refractory compounds and producing output with great biodegradability, which greatly facilitates the subsequent biological treatment [22].

\subsection{Wastewater Treatment Using A2O-MBBR System}

Wastewater, after being treated by the internal electrolysis process, was further treated by A2O-MBBR with operating parameters as in Table 1. The MBBR dynamic biofilm where bacterial biomass grows on its surface played the key role in filtering particles from the inlet wastewater, thus reducing organic matter and leading to $\mathrm{BOD}_{5}$ removal or nitrification. In this experiment, MBBR biofilm with area of $1000 \mathrm{~m}^{2} / \mathrm{g}$ was used with the dosage of $2 \mathrm{~g} / \mathrm{L}$. Organic carbon was converted to carbon dioxide and leaves the system, whereas ammonia and nitrogen in organic matter were converted to nitrates through nitrification.

\subsection{1. $\mathrm{pH}$ Change in the A2O-MBBR System}

Changes in $\mathrm{pH}$ in the A2O-MBBR system reflect the metabolic capacity of the microorganism, the efficiency of pollutant consumption, the development, and the existence of specific microorganisms in reaction tanks $[7,15,18,20]$. The retention times in anaerobic, anaerobic, and aerobic treatment were 14 , 6 , and $4 \mathrm{~h}$, respectively. DO ranges in the three processes were $0.1-0.2,1-2$, and $5-8 \mathrm{mg} / \mathrm{L}$, respectively.

Wastewater treated with internal electrolysis had its $\mathrm{pH}$ adjusted to 8 before being supplied to A2O-MBBR system. After $24 \mathrm{~h}$ of anaerobic treatment in the tank, measured $\mathrm{pH}$ was around 6.2-6.5, indicating that organic acids were produced and confirming the occurrence of anaerobic fermentation. In anoxic and aerobic tank, the $\mathrm{pH}$ was higher, ranging from around 6.5 to 7.2 , especially in tanks with aeration. This indicates the presence of the heterotrophic processes, which enhanced nitrification and antinitrification.

\subsubsection{TSS Change in A2O-MBBR System}

Figure 8 shows results of TSS of wastewater after various treatment processes. Treatment using sole A2O-MBBR system reduced the TSS of wastewater from the initial TSS of 145.2 to $40.3 \mathrm{mg} / \mathrm{L}$ (efficiency 72.2\%). Combining internal electrolysis with A2O-MBBR gave similar reduction, reaching the minimum TSS of $41.6 \mathrm{mg} / \mathrm{L}$ with the efficiency of 71.3\%. All TSS results meet QCVN 52:2017/BTNMT standard (column A) for steel industry wastewater [23].

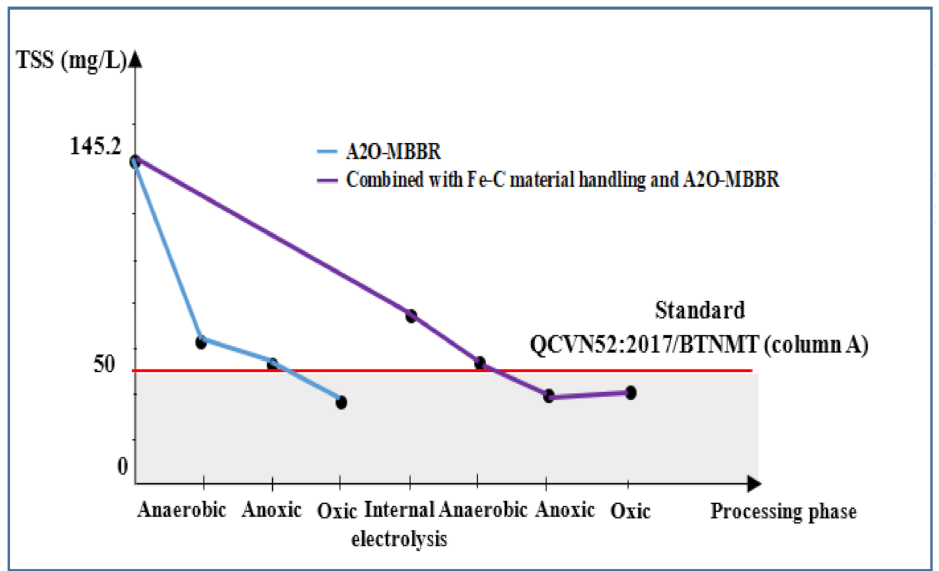

Figure 8. Treatment efficiency of TSS (mg/L) via A2O-MBBR system and through treatment of Fe-C materials combined with A2O-MBBR system. 
3.3.3. $\mathrm{COD}$ and $\mathrm{BOD}_{5}$ of Wastewater Treated Using Internal Electrolysis and A2O-MBBR System

Figures 9 and 10, respectively, illustrate $\mathrm{COD}$ and $\mathrm{BOD}_{5}$ of the wastewater during treatment processes. Largest reduction in COD could be observed to occur in aeration tanks. It is indicated that a large quantity of organic matter has been consumed by the process and that final COD and $\mathrm{BOD}_{5}$ of wastewater treated with the combinational process met the QCVN52:2017/BTNMT standard (column A).

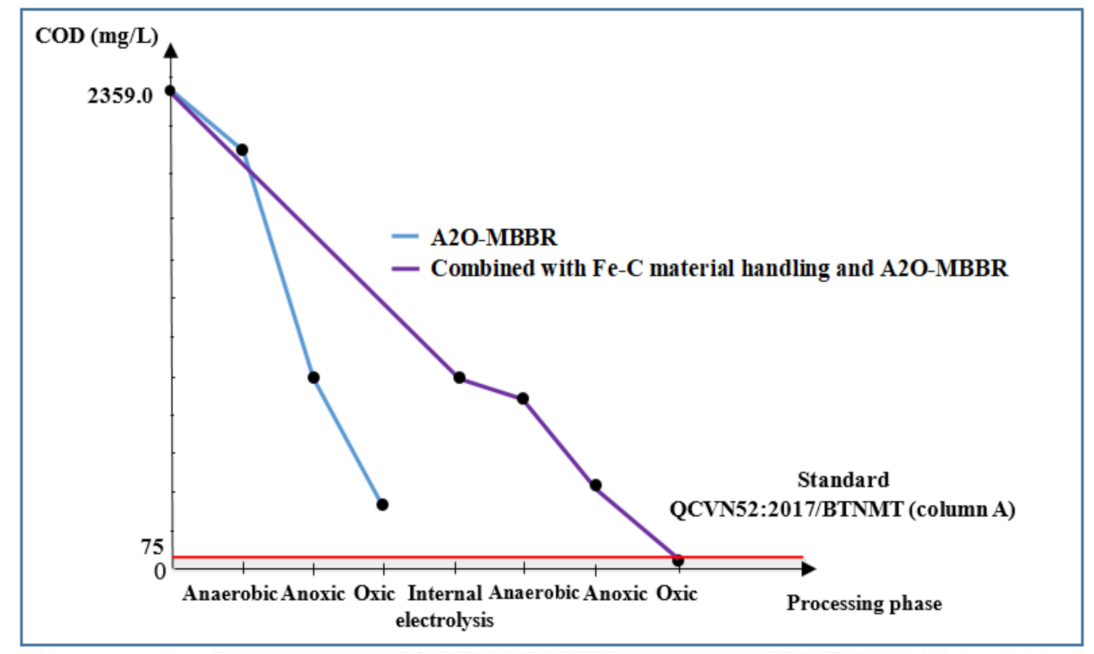

Figure 9. COD treatment efficiency $(\mathrm{mg} / \mathrm{L})$ via A2O-MBBR system and through treatment of Fe-C material combined with A2O-MBBR system.

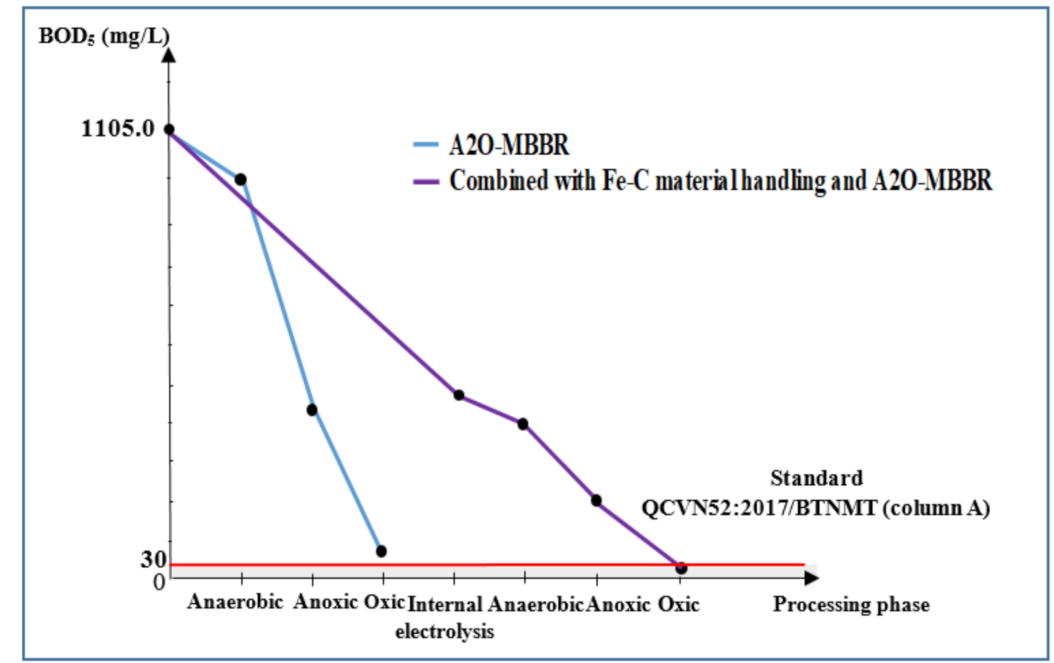

Figure 10. $\mathrm{BOD}_{5}$ treatment efficiency $5(\mathrm{mg} / \mathrm{L})$ via $\mathrm{A} 2 \mathrm{O}-\mathrm{MBBR}$ system and through treatment of Fe-C material combined with A2O-MBBR system.

The electrolysis process using Fe-C materials resulted in $\mathrm{COD}$ and $\mathrm{BOD}_{5}$ treatment efficiency of $53.7 \%$ and $56.7 \%$, reaching the COD and $\mathrm{BOD}_{5}$ of 1032.0 and $498.0 \mathrm{mg} / \mathrm{L}$, respectively. These values do not meet QCVN 52:2017/BTNMT standard (column A) for steel manufacturing industrial wastewater. On the other hand, the A2O-MBBR system seemed to be capable of removing COD and $\mathrm{BOD}_{5}$ at high efficiency. To be specific, after the input wastewater having COD and $\mathrm{BOD}_{5}$ of 2359.0 and $1105.0 \mathrm{mg} / \mathrm{L}$, respectively, had been treated with A2O-MBBR system, the metrics were reduced to 378.7 and $68.7 \mathrm{mg} / \mathrm{L}$, which are $83.9 \%$ and $93.8 \%$ reduction, respectively. However, these results still do not meet the standard. When combining electrolysis with $\mathrm{Fe}-\mathrm{C}$ material and the subsequent A2O-MBBR system, the output water had the COD and $\mathrm{BOD}_{5}$ decreased significantly to 67.3 and 
$25.7 \mathrm{mg} / \mathrm{L}$, respectively. This corresponds to treatment efficiency of $97.1 \%$ and $97.7 \%$ and met the QCVN 52:2017/BTNMT standard (column A) for steel production industrial wastewater.

3.3.4. Total $\mathrm{N}$ and $\mathrm{NH}_{4}^{+}-\mathrm{N}$ of Wastewater Treated Using Internal Electrolysis and A2O-MBBR System Total treatment efficiency of $\mathrm{N}$ and $\mathrm{NH}_{4}^{+}-\mathrm{N}$ is shown in as Figures 11 and 12.

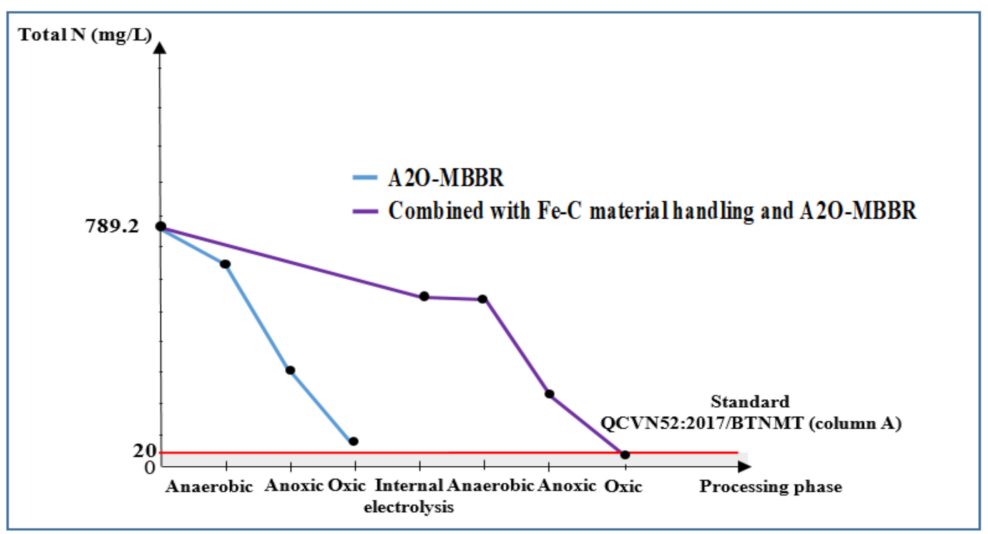

Figure 11. Total $\mathrm{N}$ treatment efficiency (mg/L) through A2O-MBBR system and through treatment of Fe-C material combined with A2O-MBBR system.

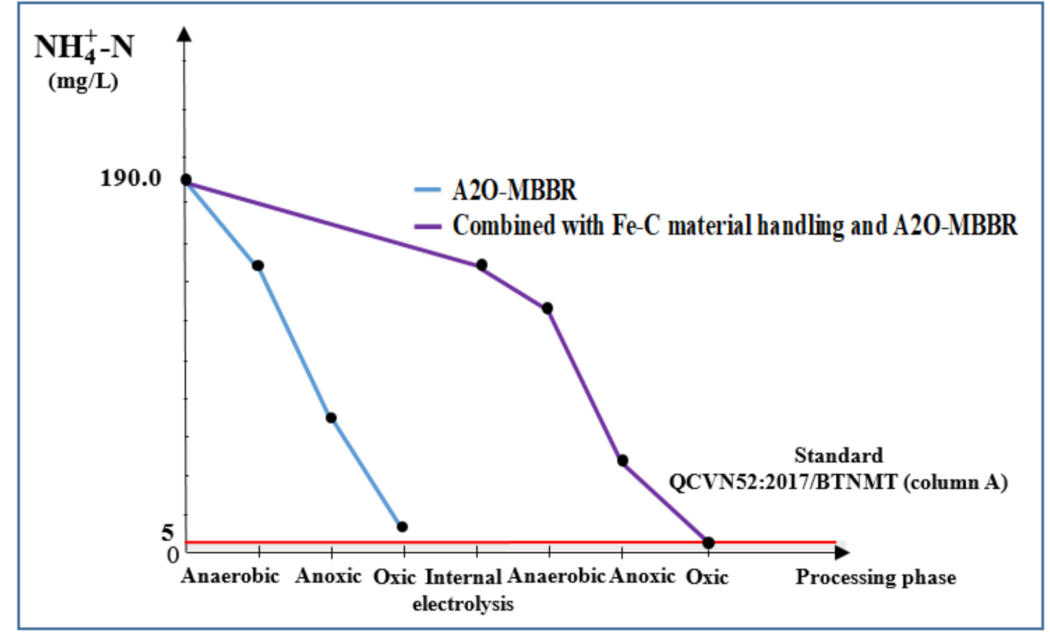

Figure 12. $\mathrm{NH}_{4}^{+}-\mathrm{N}$ treatment efficiency $(\mathrm{mg} / \mathrm{L})$ via $\mathrm{A} 2 \mathrm{O}-\mathrm{MBBR}$ system and through treatment of Fe-C material combined with A2O-MBBR system.

Internal electrolysis using Fe-C materials gave total $\mathrm{N}$ and $\mathrm{NH}_{4}^{+}-\mathrm{N}$ treatment efficiency of $35.0 \%$ and $60.1 \%$, respectively, corresponding to the remaining total content of $\mathrm{N}$ of $562.4 \mathrm{mg} / \mathrm{L}$ and $\mathrm{NH}_{4}^{+}-\mathrm{N}$ content of $156.0 \mathrm{mg} / \mathrm{L}$. These values do not meet QCVN 52:2017/BTNMT (column A) standards for steel manufacturing industrial wastewater. For the A2O-MBBR system, ammonium removal in the early operation days was low because the microbiota was not stable when exposed to new wastewater and the quantity of nitrate/antinitrifying and nitrite/antinitrite bacteria was not sufficiently high. During the operation period of 30-45 days, after the A2O-MBBR system had established sufficient initial parameters (Table 1), total $\mathrm{N}$ and $\mathrm{NH}_{4}^{+}-\mathrm{N}$ treatment efficiency reached $89.6 \%$ and $91.9 \%$, respectively, corresponding to the remaining total content of $\mathrm{N}$ of $81.9 \mathrm{mg} / \mathrm{L}$ and $\mathrm{NH}_{4}^{+}-\mathrm{N}$ content of $15.3 \mathrm{mg} / \mathrm{L}$. These values do not meet QCVN 52:2017/BTNMT (column A) standards for steel manufacturing industrial wastewater. However, the use of combinational process in which internal electrolysis precedes $\mathrm{A} 2 \mathrm{O}-\mathrm{MBBR}$ system gave total $\mathrm{N}$ and $\mathrm{NH}_{4}^{+}-\mathrm{N}$ treatment efficiency of $97.6 \%$ and 
97.5\%, respectively. The final $\mathrm{N}$ was $19.1 \mathrm{mg} / \mathrm{L}$ and $\mathrm{NH}_{4}^{+}-\mathrm{N}$ content was $4.7 \mathrm{mg} / \mathrm{L}$. These results satisfy QCVN 52:2017/BTNMT (column A) standards for steel industry wastewater.

\subsubsection{Total P of Wastewater Treated Using Internal Electrolysis and A2O-MBBR System}

Phosphorus exists in water in the form of $\mathrm{H}_{2} \mathrm{PO}_{4}^{-}, \mathrm{HPO}_{4}^{2-}, \mathrm{PO}_{4}^{3-}$, polyphosphates, $\mathrm{Na}_{3}\left(\mathrm{PO}_{3}\right)_{6}$, and organic phosphorus. This is one of the sources of nutrients for aquatic plants and a factor for pollution and promotion of eutrophication in water bodies. Excess P content in wastewater causes large algae and aquatic plants to grow rapidly, covering the surface of the water bodies, limiting the amount of dissolved air oxygen into the water. Moreover, the decomposition of dead algae and aquatic plants might also reduce dissolved oxygen, in turn, killing marine animals. Therefore, the total $\mathrm{P}$ is an important indicator in assessing wastewater pollution, and the removal efficiency of $P$ is an essential measure in any wastewater treatment process.

With internal electrolysis using Fe-C, P removal efficiency reached $47.2 \%$, resulting in total remaining P of $8.5 \mathrm{mg} / \mathrm{L}$ (Figure 13), which is unsatisfactory according to QCVN 52:2017/BTNMT (column A) standards for steel industry wastewater. On the contrary, both A2O-MBBR system and the combinational process gave very high treatment efficiency of total $\mathrm{P}$, achieving the total $\mathrm{P}$ of 3.0 (77.9\% efficiency) and $1.8 \mathrm{mg} / \mathrm{L}$ (81.6\% efficiency). Those values met QCVN 52:2017/BTNMT (column A) standards for steel industry wastewater.

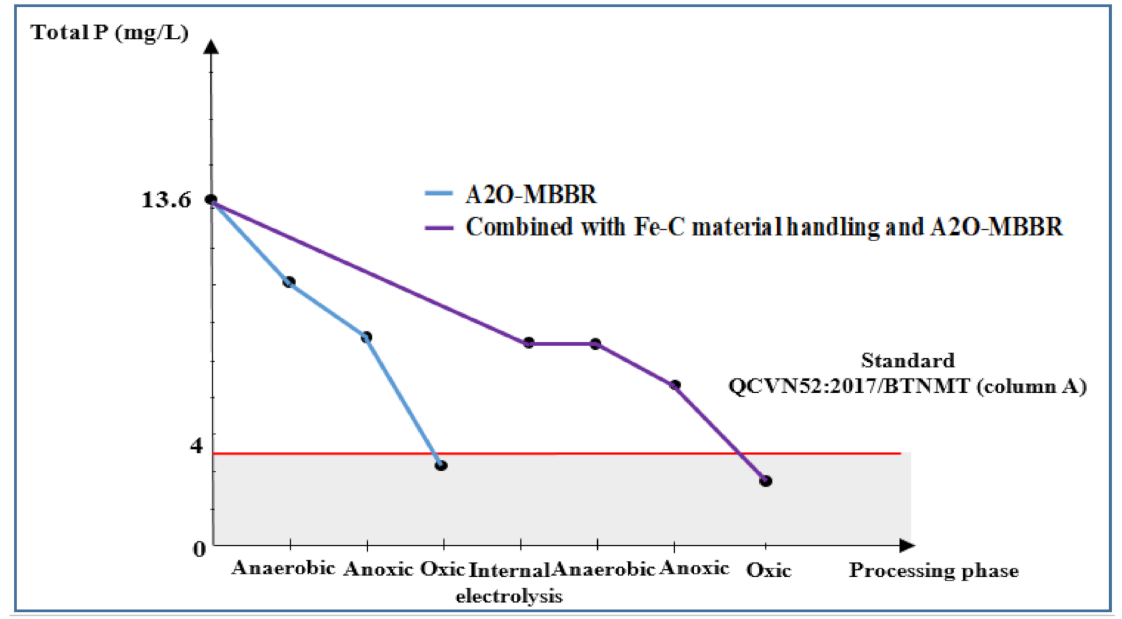

Figure 13. Treatment efficiency total $\mathrm{P}(\mathrm{mg} / \mathrm{L})$ via A2O-MBBR system and through treatment of Fe-C material in combination with A2O-MBBR system.

\subsubsection{Phenol Removal Efficiency of A2O-MBBR System}

Results of phenol treatment in wastewater are shown in Figures 14 and 15.

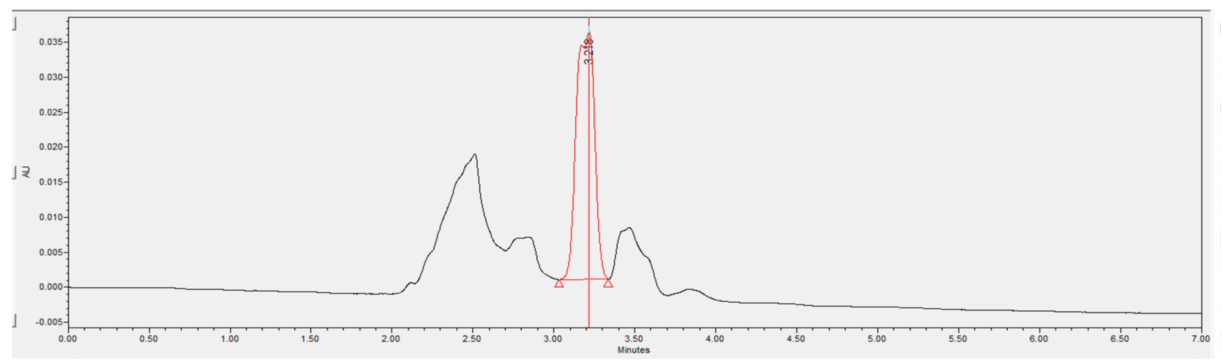

Figure 14. Chromatogram of a phenol containing wastewater sample after being treated with A2O-MBBR system. 


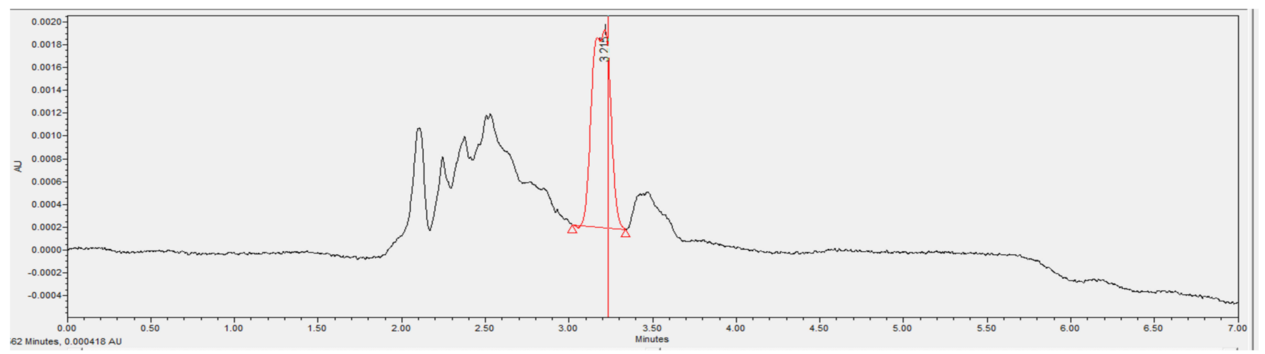

Figure 15. Chromatogram of the wastewater sample containing phenolic conjugate material processing Fe-C and A2O-MBBR system.

Overall, good phenol removal performance was observed in the chromatograms of the wastewater treated by the A2O-MBBR system. The real coking wastewater sample had its phenol concentration reduced from 172.0 to $25.8 \mathrm{mg} / \mathrm{L}$, which is an $85 \%$ removal efficiency (Table 4 ). On the other hand, the combinational process reduced the concentration of phenol from 45.9 to $0 \mathrm{mg} / \mathrm{L}$. Thus, the combination of the two treatment processes is recommended to meet the QCVN 52:2017/BTNMT standard (column A) for steel production industrial wastewater.

Table 4. Indicators of wastewater through different treatment stages.

\begin{tabular}{|c|c|c|c|c|c|c|}
\hline \multirow{2}{*}{ Indicator } & \multirow{2}{*}{ Before Treatment } & \multirow{2}{*}{ After Fe-C } & \multirow{2}{*}{$\begin{array}{c}\text { After } \\
\text { A2O-MBBR }\end{array}$} & \multicolumn{2}{|c|}{ Fe-C \& A2O-MBBR } & \multirow{2}{*}{$\begin{array}{c}\text { QCVN 52:2017/BTNMT } \\
\text { (Column A) }\end{array}$} \\
\hline & & & & After Treatment & $\mathbf{H} \%$ & \\
\hline TSS, mg/L & 145.2 & 76.5 & 40.3 & 41.6 & 71.3 & 50.0 \\
\hline $\mathrm{BOD}_{5}, \mathrm{mg} / \mathrm{L}$ & 1105.0 & 498.0 & 68.7 & 25.7 & 97.7 & 30.0 \\
\hline $\mathrm{COD}, \mathrm{mg} / \mathrm{L}$ & 2359.0 & 1032.0 & 387.7 & 67.3 & 97.1 & 75.0 \\
\hline Total N, mg/L & 789.2 & 562.4 & 81.9 & 19.1 & 97.6 & 20.0 \\
\hline Total $\mathrm{P}, \mathrm{mg} / \mathrm{L}$ & 13.6 & 8.5 & 3.0 & 2.5 & 81.6 & 4.0 \\
\hline $\mathrm{NH}_{4}^{+}-\mathrm{N}, \mathrm{mg} / \mathrm{L}$ & 190 & 156.0 & 15.3 & 4.7 & 97.5 & 5.0 \\
\hline Phenol, mg/L & 172.0 & 45.9 & 25.8 & 0.0 & 100 & 0.1 \\
\hline $\mathrm{pH}$ & 8.0 & 4.0 & $6.5-7.2$ & $6.5-7.2$ & - & $6.0-9.0$ \\
\hline
\end{tabular}

\section{Conclusions}

In this study, two wastewater treatment methods, namely, internal electrolysis with Fe-C material and A2O-MBBR process, were evaluated for treatment of real coking wastewater. The employment of the internal electrolysis alone resulted in the removal efficiencies of phenol, TSS, $\mathrm{BOD}_{5}, \mathrm{COD}$, total $\mathrm{N}$, total $\mathrm{P}$, and $\mathrm{NH}_{4}{ }^{+}-\mathrm{N}$ of $73.32 \%, 51.02 \%, 56.70 \%, 53.74 \%, 34.98 \%, 47.20 \%$, and $60.10 \%$, respectively. For the A2O-MBBR system, the figures were $85.0 \%, 72.2 \%, 93.8 \%, 83.9 \%, 89.6 \%, 77.9 \%$, and $91.9 \%$, respectively. However, the combination of the two processes gave significantly higher phenol decomposition, at $100 \%$, and moderately improved $\mathrm{COD}$, total $\mathrm{N}$, and $\mathrm{NH}_{4}^{+}-\mathrm{N}$ removal efficiency. All water indicators of the wastewater treated with the combination process also meets the QCVN 52:2017/BTNMT (column A) for steel industry wastewater. The above results suggest the possibility to deploy the application of the internal electrolysis technology combined with the A2O-MBBR biofilm in practice to treat the wastewater in the coking process.

Author Contributions: Investigation, D.T.H., V.T.N., X.L.H., H.L.N.T., T.T.D. and H.-T.N.T.; writing-original draft, D.T.H.; writing - review and editing, D.C.N. All authors have read and agreed to the published version of the manuscript.

Funding: This work was completed with financial support from the Ministry of Education and Training of Vietnam, under the project B2019-TNA-10.

Conflicts of Interest: The authors declare no conflict of interest. 


\section{References}

1. Kang, M.; Chen, Q.; Li, J.; Liu, M.; Weng, Y. Preparation and study of a new type of Fe-C microelectrolysis filler in oil-bearing ballast water treatment. Environ. Sci. Pollut. Res. 2019, 26, 10673-10684. [CrossRef] [PubMed]

2. Zheng, X.-Y.; Jin, M.; Zhou, X.; Chen, W.; Lu, D.; Zhang, Y.; Shao, X. Enhanced removal mechanism of iron carbon micro-electrolysis constructed wetland on $\mathrm{C}, \mathrm{N}$, and $\mathrm{P}$ in salty permitted effluent of wastewater treatment plant. Sci. Total Environ. 2019, 649, 21-30. [CrossRef] [PubMed]

3. Huang, L.; Sun, G.; Yang, T.; Zhang, B.; He, Y.; Wang, X.-H. A preliminary study of anaerobic treatment coupled with micro-electrolysis for anthraquinone dye wastewater. Desalination 2013, 309, 91-96. [CrossRef]

4. Zhang, L.; Yue, Q.; Yang, K.; Zhao, P.; Gao, B. Analysis of extracellular polymeric substances (EPS) and ciprofloxacin-degrading microbial community in the combined Fe-C micro-electrolysis-UBAF process for the elimination of high-level ciprofloxacin. Chemosphere 2018, 193, 645-654. [CrossRef] [PubMed]

5. Wang, Y.; Wu, X.; Yi, J.; Chen, L.; Lan, T.; Dai, J. Pretreatment of printing and dyeing wastewater by Fe/C micro-electrolysis combined with $\mathrm{H} 2 \mathrm{O} 2$ process. Water Sci. Technol. 2018, 2017, 707-717. [CrossRef]

6. Ma, W.; Han, Y.; Xu, C.; Han, H.; Ma, W.; Zhu, H.; Li, K.; Wang, D. Enhanced degradation of phenolic compounds in coal gasification wastewater by a novel integration of micro-electrolysis with biological reactor (MEBR) under the micro-oxygen condition. Bioresour. Technol. 2018, 251, 303-310. [CrossRef]

7. Liu, M.; Wang, L.; Xiao, X.; He, Z. Fe/C micro electrolysis and Fenton oxidation process for the removal of recalcitrant colored pollutants from mid-stage pulping effluent. J. Bioresour. Bioprod. 2018, 3, 118-122. [CrossRef]

8. Ji, Q.; Tabassum, S.; Hena, S.; Silva, C.G.; Yu, G.; Zhang, X. A review on the coal gasification wastewater treatment technologies: Past, present and future outlook. J. Clean. Prod. 2016, 126, 38-55. [CrossRef]

9. Zhao, Q.; Liu, Y. State of the art of biological processes for coal gasification wastewater treatment. Biotechnol. Adv. 2016, 34, 1064-1072. [CrossRef]

10. Xu, L.; Wang, J.; Zhang, X.; Hou, D.; Yü, Y. Development of a novel integrated membrane system incorporated with an activated coke adsorption unit for advanced coal gasification wastewater treatment. Colloids Surfaces A Physicochem. Eng. Asp. 2015, 484, 99-107. [CrossRef]

11. Banu, J.R.; Uan, D.K.; Yeom, I.T. Nutrient removal in an A2O-MBR reactor with sludge reduction. Bioresour. Technol. 2009, 100, 3820-3824. [CrossRef] [PubMed]

12. Pimple, S.; Karikkat, S.; Devanna, M.; Yanamadni, V.; Sah, R.; Prasad, S. Comparison of MBR/RO and UF/RO hybrid systems for the treatment of coke-oven effluents. Desalin. Water Treat. 2014, 57, 1-9. [CrossRef]

13. Zeng, W.; Li, L.; Yang, Y.; Wang, S.; Peng, Y. Nitritation and denitritation of domestic wastewater using a continuous anaerobic-anoxic-aerobic (A2O) process at ambient temperatures. Bioresour. Technol. 2010, 101, 8074-8082. [CrossRef] [PubMed]

14. Wang, Z.; Xu, X.; Gong, Z.; Yang, F. Removal of COD, phenols and ammonium from Lurgi coal gasification wastewater using A2O-MBR system. J. Hazard. Mater. 2012, 78-84. [CrossRef] [PubMed]

15. Zeng, W.; Li, L.; Yang, Y.-Y.; Wang, X.-D.; Peng, Y. Denitrifying phosphorus removal and impact of nitrite accumulation on phosphorus removal in a continuous anaerobic-anoxic-aerobic (A2O) process treating domestic wastewater. Enzym. Microb. Technol. 2011, 48, 134-142. [CrossRef] [PubMed]

16. Dong, C.; Li, M.; Zhuang, L.-L.; Zhang, J.; Shen, Y.; Li, X. The Improvement of Pollutant Removal in the Ferric-Carbon Micro-Electrolysis Constructed Wetland by Partial Aeration. Water 2020, 12, 389. [CrossRef]

17. Zhang, M.; Tay, J.H.; Qian, Y.; Gu, X.S. Coke plant wastewater treatment by fixed biofilm system for COD and NH3-N removal. Water Res. 1998, 32, 519-527. [CrossRef]

18. Peng, Y.; Wang, X.-L.; Li, B.-K. Anoxic biological phosphorus uptake and the effect of excessive aeration on biological phosphorus removal in the A2O process. Desalination 2006, 189, 155-164. [CrossRef]

19. You, S.; Hsu, C.; Chuang, S.; Ouyang, C. Nitrification efficiency and nitrifying bacteria abundance in combined AS-RBC and A2O systems. Water Res. 2003, 37, 2281-2290. [CrossRef]

20. Yang, Z.; Ma, Y.; Liu, Y.; Li, Q.; Zhou, Z.; Ren, Z. Degradation of organic pollutants in near-neutral pH solution by Fe-C micro-electrolysis system. Chem. Eng. J. 2017, 315, 403-414. [CrossRef]

21. Zhang, J.; Zhang, Y.; Quan, X. Electricity assisted anaerobic treatment of salinity wastewater and its effects on microbial communities. Water Res. 2012, 46, 3535-3543. [CrossRef] [PubMed] 
22. Wu, S.; Qi, Y.; Fan, C.; Dai, B.; Huang, J.; Zhou, W.; He, S.; Gao, L. Improvement of anaerobic biological treatment effect by catalytic micro-electrolysis for monensin production wastewater. Chem. Eng. J. 2016, 296, 260-267. [CrossRef]

23. Ministry of Natural Resources and Environment of Vietnam. National Technical Regulation on Wastewater of Steel Industry; QCVN 52:2017/BTNMT; Hanoi, Vietnam, 2017. Available online: http://vea.gov.vn/Quy\% 20chun\%20Vit\%20Nam/QCVN\%2052-2017-BTNMT.pdf (accessed on 18 September 2020). 